\title{
Romantismo e objetividade: notas sobre um panorama do Rio de Janeiro*
}

\author{
Margareth da Silva Pereira \\ Universidade Federal Fluminense \\ Instituto do Patrimônio Histórico e Artístico Nacional
}

Entre o final do século XVIII e os primeiros anos do século XIX surgiram, primeiro em Londres e depois em Berlim e Paris, certas telas que se comparadas à produção artística do período eram, no mínimo, curiosas. Chamadas "panoramas", estas telas, destifuídas de molduras, de começo ou fim, eram exibidas em construções circulares e apresentavam traços inovadores, não só na forma como eram mostradas ao público mas, também, no formato, nas dimensões e no tratamento temático.

De início, as multidões contemplaram estes "quadros", maravilhadas. Intelectuais, artistas e cientistas sentiram-se também estimulados a especular sobre as novas perspectivas teóricas que ofereciam estas imagens e sua forma de exibição. Entretanto - como "espécimens" de transição - os panoramas traziam em si os germes de uma nova forma de sensibilidade que, estimulando globalmente o seu surgimento, em pouco tempo, decretaria sua obsolescência enquanto meio privilegiado de reflexão científica e artística.

fato é que os panoramas sofreriam um processo de evolução ambíguo e teriam alguns dos seus aspectos explorados, gerando investigações plásticas, técnicas e estéticas e outros parcialmente silenciados, talvez, até hoje. Pode-se dizer que os aspectos mais superficiais e mecânicos que se buscou teorizar tiveram uma assimilação e vulgarização rápidas. Já o questionamento de cunho filosófico e moral das noçōes de tempo e de espaço entendidas enquanto um "em si" - fomento da sua proposta de fruição estética - seria minimizado, se não francamente refreado, em seus efeitos e desdobramentos.

\footnotetext{
* O eixo das reflexôes sintetizadas neste texto foi organizado e exposto no Colóquio Brasileiro de História da Arte, realizado na USP, em outubro de 1993. Embora a versão atual guarde ainda as características do ensaio redigido à época, somos gratos ao estímulo do professor Ulpiano $\mathrm{T}$. Bezerra de Meneses, que colocando generosamente obras de sua biblioteca à nossa disposição, permitiu que várias partes do texto original pudessem ganhar melhor forma.
} 
1. Obras recentes dando mostras de exaustivas pesquisas, como Bordini (1984) e Pleissen ed. 1993) vêm tratando dos panoramas mas contemplando-os em um largo arco de tempo, o que malgrado a extensão da empresa, acaba por diluir os pontos de ruptura e as diferenças do papel social e cultural de um mesmo suporte

2. O espírito e o estilo Biedermeier designam $o$ universo privado e 0 modo de vida, intímo, burguês tal qual se evidência por volta de 1840 com a multiplicação de projetos de residências que se distinguem das "villas" $e$ o gosto pelo pequeno e confortável (cf. Sedlmeyer 1959: 3638). Tendemos, ao contrário de Comment (1993: 102-103), a datar 30 anos mais cedo, por volta de 1840 no máximo, o fim da primeira geração de panoramas. São sintomas, sucessivamente desde a década de 1830: a invenção do, a invençâo do panorama-salon, a invenção do daguerreótipo, a série de vistas urbanas de cidades de Alfred Guesdon a vôo de pássaro a partir de 1840 .
Em síntese, parece que há ciclos, evoluções, involuções e deslocamentos na história da concepção, difusão e recepção dessas telas que necessitam ser melhor apontados'. Desde a década de 1830, por exemplo, algumas das questões que ocuparam seus criadores e os intelectuais que haviam acompanhado suas primeiras experiências seriam aprofundadas e desenvolvidas, mas deslocando-se para outros suportes.

A partir dos anos 1840, as conquistas obtidas pelos panoramas restringem-se cada vez mais, apenas, aos aperfeiçoamentos técnicos e de exploração comercial e pode-se dizer que aqui começaria, justamente, o seu lento processo de mutação e obsolescência. Tanto os temas que predominariam nas exibições quanto a própria escala, marcadamente grandiloquente, que assumiriam, contribuiriam no sentido de neutralizar o universo ideológico, complexo e libertário que thes dera forma.

É quando se tornaram grandes e bem sucedidas empresas, atingindo um gigantismo e uma verossimilhança espetaculares do ponto de vista da figuração realística da cena tratada, que os panoramas cessam de contribuir criticamente para a história da arte e da ciência. Gradualmente "domados" pelo espírito Biedermeier ${ }^{2}$ à medida que tomava impulso a "revolução visual" que haviam ajudado a estimular, os panoramas vão deixando de ser a experiência construída artificiosamente pela ciência humana, de iniciação ao sentimento do belo ou do sublime - como em seus inícios alguns pretenderam tornando-se apenas grandiosas e pitorescas vistas, tingidas de exotismo ou de um sentido pedagógico primário. Tornar-se-iam, sobretudo, um "inocente" divertimento para os olhos.

De fato, os mesmos traços que nos permitem resgatar e afirmar a importância destas telas na construção de novas formas de comunicabilidade estética, ao serem progressivamente absorvidos, acabariam por provocar, primeiro, a vulgarização deste gênero de pintura, transformando-o em fenômeno de moda e mais tarde seu esquecimento.

Substituidos no século XX cada vez mais pelo cinema - herdeiro direto, enquanto veículo, de suas propostas estéticas -, Os panoramas passaram a ser um divertimento datado, desinteressante até mesmo enquanto fenônemo de consumo e da indústria de lazer das sociedades urbanizadas e industriais.

Incômodas e pouco rentáveis, as rołundas especialmente construídas para exibir estas telas foram destruídas sob a pressão da valorização das áreas que ocupavam. Quanto às telas, propriamente ditas, que subsistiram, pouquíssimas poderiam ser, mesmo parcialmente, associadas à poética dos panoramas em sua fase de maior vigor crítico e especulativo (Comment 1993: 102-103). O lento processo de esquecimento dessas pinturas e de sua forma de exibição teria ainda como cúmplice as próprias reservas que a historiografia da arte cultivaria durante muito tempo em relação ao século XIX.

Hoje, as raríssimas salas de exibição dessas telas em funcionamento, nem de longe reconstituem o "tempo dos panoramas". O que restou deste momento forte de investigações estéticas - pequenas figurações avulsas ou em série de vistas de cidades e de montanhas nevadas, imagens de ruínas, de cenas de batalhas ou de frotas - são vestígios incapazes de testemunhar a 
ambição do projeto de reorganização geral do campo do visível do qual foram sintoma, suporte e instrumento de estudo. Esboçados à crayon, às vezes aquarelados ou gravados, estes desenhos acabam classificados nos acervos, apenas como mais uma variante da pintura de paisagens, meras vistas.

Esquece-se que foi a partir destes esboços e croquis ampliados que os panoramas exacerbaram a faculdade de olhar para que intelectualmente as idéias de ver e agir pudessem ser experiementadas, isto é, para que visão e ação fossem consciência. De fato, os primeiros panoramas instalaram, total e radicalmente, a dúvida na experiência de contemplação. Buscaram ser um modo de estranhar a própria estranheza e artificialidade do que "naturalmente" chamamos realidade. Mas parece que se com aquelas telas fixamos o olhar em tudo que nos envolve, apenas aprendemos a revestir o visivel da noção de espetáculo sem conseguir interrogar - como alguns dos seus teóricos tanto insistiam em chamar a atenção - sobre a própria operação que cada um realiza.

Assim, os panoramas, que tanto ensinaram a ver, tornados "imateriais" e "invisiveis" deixaram de "ter existência" e apenas, com um certo esforço, começam a ser avaliados em suas singularidades e contribuições centrais para a cultura visual e pictórica do século XIX e XX. Destituídos da lógica cultural e social na qual estavam indissociavelmente imersos e onde operavam ativa e criticamente, os seus vestígios nada mais são do que amarelados pedaços de papel, de resolução artística muitas vezes duvidosa e sem função, que se empilham em gavetas e se acondicionam, talvez por nostalgia mas, certamente, sem saber exatamente porque.

Se observarmos estas obras e os debates que suscitaram entre 1790 e 1830, isto é, nestes anos que balizam seu aparecimento e a tomada de consciência pelos mais importantes intelectuais do período da própria ruptura que representavam, certamente nos surpreenderíamos. Seriamos obrigados a considerar o papel que desempenharam - malgrado os recuos - na história moderna das artes visuais desestabilizando o "sistema" acadêmico e oficial de arte, introduzindo novas ordens de questões aos críticos e artistas.

Este movimento de renovação possui tal força que na segunda metade do século XIX - quando os panoramas se vulgarizam e tornam-se cada vez mais celebrados, particularmente nas Exposições Universais - a experiência vivida e pensada naqueles trinta ou quarenta anos iniciais já havia engendrado outras linguagens no campo da pintura ou, até mesmo, dera nascimento ou começava a inspirar a pesquisa, como já sublinhamos, de outros "meios", como, primeiramente a fotografia e, pouco mais tarde, o cinema.

\section{Panorama e panoramas}

Nos dicionários atuais "panorama" quer dizer "paisagem ou vista" ou "visão sucessiva e completa de um assunto em toda sua amplitude". Ao contrário desta definição, estamos entendendo por panorama um gênero de pintura que reproduz uma cena dada, como se o espectador girasse em torno de um eixo e pudesse contemplá-la de todos os ângulos possíveis, isto é, como 
se realizasse uma volta de 360 graus. Este modo de figurar o que circunda o homem tem sua invenção, amadurecimento e vulgarização, relativamente bem demarcados.

Na verdade, a palavra panorama é um neologismo, criado no final do século XVIII, justamente para designar este gênero de pintura circular, que por ser absolutamente novo, exigia a invenção também de nova palavra para designá-lo. O sucesso desta forma de exibição de cenas pintadas levaria à generalização do uso da palavra que passaria a ser sinônimo, como sabemos, de tudo que é abrangente, completo, total, exaustivo.

A se considerar os dicionários, tem-se a impressão de que a palavra "panorama", como é usada hoje, teve seu sentido ampliado. Espera-se, entretanto, conseguir demonstrar o contrário, isto é, que ao deslocar-se o emprego da palavra - da experiência estética precisa, proporcionada nos panoramas, para qualquer atitude, objeto, gesto ou empreendimento que se deseja grandioso ou completo - houve um rebaixamento da proposta, pelo menos em suas potencialidades.

É como se a experiência estética que os panoramas buscaram intensificar (pela visão, evidentemente) tivesse sobrevivido nas artes visuais, mas de modo fragmentário (na pintura, na arquitetura, na escultura... isoladamente) e, assim, dentro de parâmetros culturalmente menos desestabilizadores. Por outro lado, a sua generalização - isto é, sua ambição de atingir o coletivo, as massas, todo homem, qualquer homem - parece ter se realizado mas amparada por um sentido ora explicitamente pedagógico (como por exemplo no desenvolvimento da museologia ou na idéia oitocentista de monumento) ora narrativo (como no que se tornou o cinema). Num certo sentido, culturalmente, teria se detido no que o tempo dos panoramas buscou ultrapassar e transformar em atitude generalizada. Isto é, deteve-se no entendimento do visível enquanto exterioridade, o que, de certo modo, viria a refrear a radicalidade de sua proposta.

De fato, hoje, a palavra está de tal forma integrada à linguagem moderna que sequer lembramos do seu sentido primeiro. Já não nos detemos no campo mental que produziu sua "invenção" enquanto artefato artístico e nos legaria heranças que começamos, apenas, a desvelar.

Um tema e seus problemas

Embora nesta última década alguns estudos tenham sido feitos sobre - tema dos panoramas, estes trabalhos em sua maioria ainda trazem as marcas dos grandes mapeamentos, nos quais predominam enfoques que contemplam sobretudo a sua difusão e recepção enquanto fenômeno de massas ou tecem indiscriminadamente a história do seu nascimento e morte, sem discernir os seus matizes.

O seu engendramento num momento cultural preciso, as inflexões e as diferenças de propostas em certos países ou até mesmo entre ateliers e criadores em um mesmo país, não foram, assim, ainda suficientemente estudados. Por outro lado, a cultura "ocularcentrista" do século XVIII, examinada em seus pontos de contato com a emergência dos panoramas e a 
Naturphilosophie começam, apenas, a ser vislumbradas. Avaliamos seu impacto enquanto "objeto artístico" destinado a ser apropriado pelas novas massas urbanas sem considerar as noções de mobilidade e reprodutibilidade que inauguram, já apontando para ainda uma outra mudança no estatuto da arte. Ignoramos, enfim, o processo novo de criação de imagens que - em sua natureza e em seus fins - esboça os próprios fundamentos do olhar contemporâneo ${ }^{3}$.

Em consequência, as relações entre a proposta dos primeiros panoramas e o entendimento moderno da arte como "agir crítico". não foram, pelo menos de maneira frontal, ainda tratados. Também, em sentido mais amplo, a própria articulação entre sua proposta, a constituição da sensibilidade moderna e a experiência americana - justamente enquanto experiência privilegiada de contemplação da natureza e de ante-cena da modernidade são ainda um campo rico de perspectivas a espera de novos estudos ${ }^{4}$.

De certa forma, repetindo o que aconteceu com as telas e suas rotundas, os estudos sobre os panoramas vêm se multiplicando, tornando o tema banalizado, enquanto continua-se a ignorar as reflexões surgidas em torno do seu engendramento ou de sua fruição como acontecimento estético total.

De fato, parecem ainda pesar sobre a recente historiografia a respeito dos panoramas os limites dos horizontes disciplinares. Em síntese, a produção historiográfica recente - especificamente dedicada aos panoramas - parece intimidada e pouco a vontade para enfrentar uma proposta plástica, estética, reflexiva, que insistia em sublinhar - como raras vezes de modo tão intenso - que - conhecimento não opera nem por especialização, nem por agregação, mas, ao contrário, a partir de uma inteligibilidade unitária dos problemas.

Resulta, talvez, daí, uma visão "parcial" justamente no trato de uma matéria que em sua "natureza" preconizava os apagamentos de fronteiras entre razão e sentimento, entre ciência, arte ou filosofia. E insistia em afirmar que a história não era o desfilar confortável das visões cristalizadas sobre o passado, mas o desafio de atualizá-lo e, criticamente, com ele, ser e construir, o seu próprio tempo.

No campo da historiografia da arte, poucos trabalhos se detiveram sobre a pintura de panoramas em suas ambições estéticas (apud Recht: 1989), embora seja notável nestes últimos dez ou quinze anos um interesse - um Zeitgeist - que vem provocando reflexões sobre assuntos correlatos e nestes últimos cinco anos um empenho em retirar o assunto do esquecimento.

Especificamente em relação à temática dos panoramas e a outras que the são indissociáveis, alguns estudos desenvolvidos ainda nos anos 1960, por Jean Starobinski e na década de 1970, por Michel Foucault devem ser citados à medida que contribuiram para, a partir de análises de obras de arte e da visualidade, no caso do primeiro, e a partir do campo epistemológico, no caso do segundo, retomar e enfatizar a problemática justamente da visão e da centralidade do olhar na cultura moderna.

Ainda que publicações recentes chamem a atenção para as manifestações de "hostilidade à primazia do olhar", na obra, por exemplo, de Foucault (apud Jay: 1993), é indiscutivel o impacto de seu pensamento sobre a
3. Na historiografia dos anos 1980/90 dedicada ao tema específico, o livro de Bordini (1984) parece ser aquele que mais oferece pesquisas sistemáticas e possibilidades de desdobramentos. Salientem-se ainda as pistas produtivas que $o$ livro de Recht (1989) traz para certas questões envolvendo os panoramas. A palavra "ocularcentric" foi cunhada por Martin Jay (cf. 1993).

4. A partir de meados da década de 1980 o entendimento da América como antecena da modernidade vem merecendo atenção e engendrando estudos (Cohen \& Damisch: 1993 e Cohen 1995), no campo da arte e da arquitetura. Estes estudos, todavia, são restritos à América do Norte e mantém-se, assim, um entendimento da modernidade, sobretudo enquanto estilo e/ou modo de vida especifico. 
historiografia, inclusive da arte, a partir daqueles anos. Seus trabalhos, ao lado dos de Starobinski, entre outros, estimulariam a produção de diversas publicações sobre as "visões" de história lainda, quando se fala de natureza ou da pintura de paisagens) ou sobre as formas de controle do imaginário: temas que se entrecruzam na pintura de panoramas.

Starobinski, que batizara, sintomaticamente, sua coleção de ensaios publicados nos anos 1960, como L'oeil vivant, analisou, mais tarde, particularmente, em L'invention de la liberté, a produção artística e a visualidade do século XVIII em suas articulações com as idéias de liberdade e história de forma instigante. Foucault, ao contrário, deteve-se, sobretudo em Surveiller et punir, no exame das formas de controle deste 'enorme e surpreendente poder' que os homens tomam consciência de possuir dentro dos limites de sua própria e irredutível humanidade. Como se sabe, deteve-se nos estudos dos espaços e dos mecanismos de vigilância, particularmente das prisões panóticas que surgem no século XVIII.

A partir dos anos 1980, inúmeros foram os trabalhos instigados por estes livros que, incidindo uns sobre os outros, desenharam novos temas de estudo no campo da arte como as revisões sobre o barroco e o romantismo, o interesse pela pintura de paisagem, pelos relatos e pela iconografia de viagens $e$, recentemente, os novos estudos sobre o americanismo ou a própria emergência da noção de paisagem. Pode-se dizer, em resumo, que o tema comum que percorre essa literatura é o que Starobisnki designara em seu livro como "reação poética à paisagem" e a importância que a visão assume na cultura ocidental pósrenascentista, particularmente após a "era das descobrimentos".

Como se percebe, neste últimos quinze anos, a historiografia vem explorando, de forma cada vez mais sistemática e generalizada, a gênese e os processos de teorização, aceitação ou recusa do entendimento da modernidade não enquanto estilo, ou período temporal, mas como o exercício de uma consciência e sensibilidade atópicas.

Ora, a compreensão da comunicação emotiva moderna em seu atopismo e o aguçamento de racionalização dos dispositivos tanto de estímulo quanto de controle dessa "vertigem" dos sentidos, indissociável do apelo ao exercício da razão, é o que está no centro do modo de formalização e enquadramento do visível, implícito nos panoramas.

Nosso trabalho toma como núcleo de estudo um panorama do Rio de Janeiro composto por uma sequência de 8 aquarelas medindo cada uma $0,51 \mathrm{~m} \times 0,39 \mathrm{~m}$, não assinado e com anotações a lápis, publicadas na revista belga Archives d'Architecture moderne, em 1990 (Figura 1). Estas aquarelas pertencem aos herdeiros de um dos membros da Missão Artística Francesa de 1816, pouco conhecido, arquiteto, aluno de Grandjean de Montigny, LouisSynphorien Meunié (cf. David-Roy: 1990; Pereira: 1992).

Embora o desenho não seja datado, sabe-se que Meunié retorna a Paris em fins de setembro de 1822, logo após, portanto, a proclamação da Independência do Brasil. Nos desenhos, uma cena parece deliberadamente querer registrar este acontecimento, uma vez que se vê em primeiro plano uma comitiva da qual faz parte, em uniforme da Guarda Nacional, o Imperador e 
ainda, a Imperatriz e José Bonifácio. Entretanto, parece que a tomada da cena foi feita algum tempo antes já que, nas notas escritas a mão lê-se, no verso da primeira aquarela:

"J'ai pris ces vues du fort dit Castello en haut de la colline de la Misericórdia. C'est dans ce fort que sont les signaux. Il est deux ou trois heures du soir. La saison est l'été. Le vent souffle de la mer. La marée commence à descendre" lapud David-Roy: 19901 .

Mas quem é este " $j e$ " que contempla a baía de Guanabara? A pesquisa que desenvolvemos em torno deste panorama revelou múltiplos interesses, a começar por aquele da autoria. De fato, este Panorama da cidade do Rio de Janeiro, é normalmente atribuído a Felix-Emile Taunay, como se sabe, também membro da Missão de 1816. Felix-Emile e Louis-Synphorien Meunié, tinham quase a mesma idade e é provável que o segundo tenha auxiliado o primeiro na pintura de seu panorama, embora a família de Meunié identifique a caligrafia como sendo sua: questões que ainda exigem novas pesquisas e tentativas de respostas.

Sabe-se que uma grande ampliação desta obra foi realizada e exibida em Paris em 1824, em uma rotunda já destruída da Passage des Panoramas. $O$ sucesso desta mostra parisiense levou a que fossem feitas inúmeras tiragens desta vista do Rio. Localizamos reproduções deste panorama em arquivos cariocas e em coleções particulares que apresentam pequenas diferenças em relação ao desenho original. Notícias sobre este sucesso também deram origem a que se patenteasse um novo aparelho ótico, chamado panorama-salon, isto é, um aparelho portátil que foi colocado no mercado francês, para que em suas residências cada um pudesse contemplar, individualmente, suas vistas prediletas (Nepveu, ed. 1830). Voltaremos a este ponto.

Buscaremos situar a história desses pequenos pedaços de papel pintado, começando por alguns esclarecimentos. No Brasit, quase nada foi escrito sobre panoramas chamando-se todavia a atenção para alguns trabalhos dos historiadores Donato Mello Junior, Gilberto Ferrez (1966), Elza Peixoto Ramos (1982) e mais recentemente, algumas referências sobre o tema, no catálogo da exposição O Brasil dos viajantes (Beluzzo: 1994).

Donato Mello Junior dedicou-se ao estudo de um panorama do Rio de Janeiro pintado por Vitor Meireles e Langerock, na segunda metade do século XIX, mas não publicou trabalhos específicos sobre o tema.

Gilberto Ferrez dedicou dois textos a "panoramas" do Rio de Janeiro. $O$ primeiro, na verdade o Prospecto da cidade do Rio de Janeiro, pintado em finais do século XVIII por Vilhena, não é um panorama, segundo o entendimento que estamos dando, aqui, à palavra, embora a forma como são "montadas" as informações sobre a cidade revele preocupações comuns ao gênero (Pereira: 1988). O outro trabalho de $G$. Ferrez (1966), este sim, trata de um panorama realizado pelo inglês Burchell, em 1825, e se intitula $O$ mais belo panorama do Rio de Janeiro (Figura 2). Sobre este trabalho, o historiador publicou curiosa notícia histórica em que chama a atenção para o fato de o 
original de Burchell ter sido ampliado e exibido em Londres em 1828, no Panorama existente em Leicester Square. Segundo Ferrez, na pequena nota distribuída por ocasião da mostra, o autor do texto se "enganava" na data de realização dos desenhos originais (1825), fazendo constar que haviam sido feitos em 1823 (isto é, como vimos, um ano antes que o trabalho do membro da missão francesa fosse exibido em Paris) (Ferrez: 1966).

No que tange ao período contemplado neste texto, saliente-se a contribuicão de Beluzzo (1994) em reunir alguns panoramas que enfocaram cidades brasileiras.

De nossa parte, iremos abordar - nos limites deste texto - três ordens de problemáticas que possuem nítidas articulações com este gênero novo de manifestação artística, antes de enfocarmos o panorama do Rio de Janeiro, propriamente dito. Buscaremos explorar em que "quadro" de possibilidades artísticas, técnicas e epistemológicas podemos, eventualmente, inserir aquelas pequenas e prosaicas imagens.

Primeiramente, tentaremos mostar como, no campo da pintura, os panoramas explicitam questões relativas ao suporte; à escala do que é figurado; à função e ao uso da cor, ao "enquadramento" da cena e sobretudo quanto ao seu "realismo", que formam o núcleo da revolução no estatuto da arte, que torna-se evidente, particularmente no campo da pintura, a partir da segunda metade do século XIX. Através da atenção a estes temas e dispositivos, artistas e teóricos retomam em suas investigações certas preocupações quanto às relações entre sujeito e objeto, fortemente presentes no período barroco, que são formativas do olhar moderno (Argan: 1975).

Tentaremos também apontar para uma segunda ordem de questões para as quais os panoramas procuram formular uma possibilidade de síntese. De fato, estas telas se organizam a partir de uma busca de fusão entre arte e ciência, percepção, imaginação, razão, insistindo em unir a objetividade à subjetividade e celebrar a identidade do exterior e do interior. Essa atitude, própria do romantismo e da Naturphilosophie (cf. Gusdorf 1985 e 1993), revela a busca de uma verdade fenomenal, "unitiva", que reage ao processo de especializacão, fragmentação e isolamento de dimensões da realidade humana promovido pelo cientificismo pós-enciclopedista. "A fórmula Hen kai Pan $1 \mathrm{O}$ Um e o Todo), colocada na moda por Lessing, tornava-se uma das palavras-chave da época". (Gusdorf 1985: 74)

Mais do que se imagina, os panoramas e as discussões que provocam estão ligados às experiências e às pulsões que levaram ao nascimento da fotografia e do cinema e, sobretudo, a essa sensibilidade nova, romântica, que aspira trazer à existência humana - como uma chama breve e intensa - a intuição da totalidade e do absoluto.

Por fim, alguns esclarecimentos devem ser feitos sobre a temática privilegiada nas reflexões da segunda metade do século XVIII, quando surgem os panoramas, e aquelas que se fixaram, quando se tornaram efetivamente fenômeno de massa. De fato, mostraremos como este gênero de pintura ao eleger em seu momento de maturidade - entre 1810 e 1830 - vistas urbanas como "assunto", renega as visões arcadianas e idílicas inspiradas por um desejo de harmonia com a natureza. A fixação da temática urbana, não só 
aponta certas direções em relação ao desenvolvimento da proposta, ela também sublinha, como ao mesmo tempo contribui para o processo de construção da idéia de cidade enquanto totalidade, que é solidário da emergência de uma visão, também nova, em relação à história e às realizações humanas.

Neste sentido, ainda que aquelas telas tenham buscado ultrapassar a cisão sujeito $x$ objeto, paradoxalmente, a nova forma de figuração da paisagem urbana que desenvolvem leva à "objetivação" da cidade, isto é, à visão e ao entendimento da cidade enquanto "unidade" social e física.

É o reconhecimento da cidade como objeto total do olhar que, dentre outros fatores, permite a construção de um discurso que se pretende autônomo e "cientificamente crítico" em relação ao espaço urbano histórico. A pura "objetualidade" da cidade, própria da neutralidade exigida pelo urbanismo nascente, será plenamente explicitada somente com um novo modo de figuração: as perspectivas urbanas em vôo de pássaro e que proliferam a partir de meados do século XIX.

A visão urbana total, tornada primeiro possível (com os panoramas), sofre um deslocamento, tornando-se "distanciada" e "científica" (com as vistas em vôo de pássaro). Esta segunda forma de figuração é solidária da ação dos primeiros urbanistas. Pouco a pouco constataremos a emergência de teorias de intervenção que pregam correções e reformas na cidade através de projetos globais e articulados: os primeiros projetos panorâmicos - já no sentido dominante, hoje, da palavra.

Em contrapartida, quase em paralelo, a ampliação também da dimensão doméstica, íntima, privada começa a desvelar a ambiguidade da herança dos panoramas. Também nestas telas, repete-se, como comenta Sennet (1990 103) o deslocamento do ideal de gravidade, até mesmo torturado da segunda metade do século XVIII, que por um momento se pensou reter. De fato, ele seria vencido, anteriormente, pelo desejo de flânerie nos jardins idílicos e agora, progressivamente nestas telas, por um sentimento de curiosidade pelo espetáculo anônimo - mas visto à distância - da grande cidade.

Na verdade, nossa insistência em precisar o significados que atribuimos à palavra panorama, em especificar sua forma de exibição (circular), em delimitar certos períodos de maior interesse para o estudo do gênero (1790-1830), em chamar a atenção para o tema figurado (vistas urbanas), em sublinhar exatamente a data de concepção de um (1822) ou outro (1825) "desenho panorâmico" sobre o Rio, ou comentar sobre os suportes e sutis diferenças entre reproduções de um mesmo desenho-base, deve-se ao fato de que nenhum destes aspectos pode ser considerado detalhe aleatório de menor importância. Estamos diante de indicadores de rupturas, deslocamentos, recalques que culturalmente foram processados na própria formação de uma visualidade que se interroga sobre os seus modos de operação.

O olho que tudo vê

Foi no ano de 1787 que o pintor escocês Robert Barker solicitou e obteve a patente de uma invenção que seria batizada, pouco mais tarde, 
"panorama". Numa construção circular, o espectador é conduzido por corredores escuros até o centro de uma plataforma. A ausência de luz e o percurso são concebidos para que, gradualmente, embaralhem sua percepção e seus sentidos de orientação. De repente, ele se vê, assim, diante da tela que é estendida circularmente de modo a envolvê-lo e colocado no meio da cena que the é dada a ver e já não domina suas faculdades de comparação e juízo de modo pleno. A experiência desta perda de parâmetros estáveis quanto às distâncias, cores, escalas é de tal ordem, que na expressão de contemporâneos, o faz hesitar em designar "o que é natureza ou arte" (D'Helft \& Verliefden 1978).

Alguns biógrafos dizem que Barker teria inventado o princípio de exibição destas telas observando os efeitos de luz que incidiam do alto, na parede escura da cela onde se encontrava aprisionado por não pagamento de dívidas. Deixando sua imaginação vagar e preencher de cenas aquelas superfícies nuas, o pintor teria tido a idéia não só deste novo aparato para mostrar imagens mas criaria também o neologismo, formado por ele com a ajuda de duas palavras gregas: pan, que significa todo, total, e orama que significa vista. Visão total, visão da totalidade (ib.).

Curiosamente, uma outra versão sobre o momento de "invenção" do panorama por Barker o coloca em outra situação, sob certos aspectos oposta. Nessa versão, o pintor teria intuído a possibilidade de reproduzir o que via numa única tela circular, passeando na colina, chamada Carlton Hill, ao ar livre e tendo a cidade de Edimburgo a seus pés. Seria, portanto, contemplando a cidade mas também os horizontes infinitos que se descortinavam aos seus olhos, que teria adotado, na pintura, aquilo que ele mesmo experimentava, girando lentamente o olhar em sucessivos quadros (Bordini: 1984; Comment: 1993).

Independentemente da versão a ser considerada correta, a idéia de liberdade (ou a privação dela) se encontram assim na origem do novo invento que significa não apenas um gênero de pintura, mas também um modo de mostrá-la. Até que ponto o pintor escocês conheceria as idéias de controle desenvolvidas naqueles anos por Jeremy Bentham em torno do "pan-ótico", este modo moderno de construir prisões, não sabemos.

Sabe-se que em 1791, o texto de Bentham divulgando sua máquina circular de "vigiar e punir" era publicado na França, isto é apenas alguns meses antes que Barker inaugurasse, em 1792, a primeira rotunda construída para a exibição de suas telas, justamente em Leicester Square onde anos mais tarde Burchell mostrará o seu panorama do Rio. O curioso é que Barker, colocando, como fizera Bentham, o olhar no centro da arquitetura para vigiar os corpos, construia um engenho que convidava à imaginação, agora, ao sonho, ao devaneio, justamente, à liberdade.

Com este invento, Barker desejava ser considerado na tradição paisagística do século XVIII como o precursor da reconstituição artística da experiência da natureza feita pelo artista e agora apresentada a cada um. Entretanto, como já foi sublinhado por certos autores, se tomados um a um, os aspectos colocados em ação por Barker em sua "invenção" não são absolutamente novos. Na verdade, as suas preocupações são comuns na cultura européia setecentista e fundem diversas heranças. Bordini (1984) 
enumera pelo menos quatro características fundamentais presentes nos panoramas: a visão topográfica, a amplidão do horizonte visivo, a imitação perfeita e o efeito ilusionístico, que evidentemente se manifestavam, contemporaneamente, em outros suporles. $O$ que é novo é a tentativa de busca de uma síntese formal para estas questões, o que também só se compreende se num cotejamento com outros temas caros à época.

Trataremos aqui destas características, chamando atenção para a circularidade da forma, a preocupação com a luz e o movimento e a centralidade do espectador, mas buscando articulátos, também às reflexões da Naturphilosophie e do romantismo.

\section{Tromperies}

La nature à coup d'oeil - é com esta expressão francesa que Barker descrevia a "impressão" que o seu aparato deveria causar através da exibição de vistas da natureza a céu aberto realizadas a óleo, afresco, aquarela, crayon ou qualquer outro modo de pintura ou desenho. É evidente que a preocupação nałuralística e mimética buscada por Barker em suas telas, por exemplo, não era nova.

De fato, no século XVIII o tema do caráter "parlant" da arte torna-se o centro das teorizações do período. A partir de então, um número cada vez mais importante de artistas e escritores começa a sistematizar as reflexões sobre a faculdade da arquitetura e da pintura - e de tudo o que se dá a ver - de falar aos sentidos.

Contudo, esta visão sobre os dispositivos construídos ou pictóricos como organizações plásticas, visuais, espaciais, "parlantes" se evidenciara, muito antes, pari passu com construção da moderna noção de indivíduo. Tomara a forma de uma reflexão sobre a liberdade e a história, tanto a partir da retomada e da observação dos "antigos", quanto diante da contemplação da natureza e da descoberta de um horizonte, até certo ponto "infinito", aberto ao exercício da ação, individual e coletiva, dos homens.

No campo cultural europeu, até o século XVIII, esta atenção à comunicabilidade das coisas - de todas as coisas - e portanto o entendimento da vida social em termos de "relação", de "decisão", de "juízo" insuflara evidentemente toda a produção artística barroca. Inspirara também moralistas e filósofos mas as obras e textos de uns e outros permaneciam pontuais, dispersos e, principalmente, até então, mediados pelo discurso teólogico.

Mas, se a faculdade de sentir, duvidar, julgar, agir - em liberdade - estavam algo tolhidos, e esbarravam na impossibilidade mesma de se pensar uma humanidade entregue apenas a si própria e às suas leis, o jogo ilusionístico e a imitação perfeita de muito era experimentado, dominado.

A retórica como tratado de persuadir fora um dos pilares do universo privilegiadamente visivo do barroco e não apenas no campo da pintura (cf. Argan: 1964). Lembremos do discurso dos "monumentos" e da multiplicação das cúpulas na paisagem das cidades... Aliás, no que diz respeito à arquitetura, desde muito cedo, Alberti, mirando-se no exemplo de Brunelleschi, 
já apontara para sua evidente capacidade instauradora, e, consequentemente, para sua comunicabilidade social, política. (cf. Choay: 1980)

Malgrado a predominância das temáticas religiosas, talvez tenha sido na pintura que este horizonte humano - cada vez mais humano - encontrou espaço para impor-se com maior evidência. Por outro ládo, talvez seja nesse campo que melhor possamos observar o domínio que os artistas passariam a ter da técnica de falar sobre a utilidade e necessidade das coisas ou simplesmente a falar das coisas...

De fato, embora circunscrita à "visão" de cenas - o que requisita os sentidos e os corpos, e até mesmo os inicia, mas também ampara o othar graças, sobretudo, ao formato e às molduras - a pintura barroca daria mostras tanto de uma humanização do divino quanto esboçaria - particularmente nas naturezas mortas - uma desestabilização na "naturalidade" dos objetos ou situações (temas ímplicitos à formalização dos panoramas).

Neste sentido, evoquemos rapidamente o enquadramento de corpos martirizados de Cristos seráficos e evanescentes São Sebastiões ou a "sensualidade" dos extâses místicos. Mas acompanhemos, também, essa humanidade que se expõe e se interroga diante do tempo e do olhar como na série de auto-retratos de tantos pintores - Durer, Rembrandt, Poussin... - jovens, mais ou menos jovens, já enrugados...

Pensemos na atualidade dos retratos exemplares de reis e cardeais, dos príncipes e seus cavalos, dos burgueses, seus espelhos, seus mapas-mundi, suas cidades... Detenhamo-nos, até mesmo, na "carnalidade" exposta e pertubadora de um boi esquartejado, observada de soslaio..

Ao fazer a arqueologia dos panoramas, Bordini (1984) evoca rapidamente, e reconhece, a herança barroca nos panoramas, sem contudo potencializá-la na invenção. Em texto recente, Comment (1993), ao tratar da mesma matéria, devido à generalização que introduz na sua análise, chega até mesmo a citar as pinturas de lascaux ou as tapeçarias de Bayeux nesta genealogia. Este procedimento, o leva, por uma lado, a minorar os mecanismos da retórica e do ilusionismo barroco na formalização dos panoramas, do mesmo modo que, quando abre espaço para a discussão dos trompe-l'oeil, são os tetos pintados das igrejas seiscentistas que chamam a sua atenção.

Incapaz assim de localizar historicamente as rupturas na constituição da subjetividade moderna, tende a celebrar as observações de Diderot no Salão de 1763 sobre cenas laicas - "as paisagens", como teríamos tendência a dizer de Vernet - convidando o espectador a entrar no espaço da tela, como procedimento novo (Comment, 1993: 52). Ora, voltemos aos seiscentos e deixemos que nossos olhos busquem o engano mas não olhemos, entretanto, para estes céus repletos de deuses e santos em Glória.

De fato, não está nestes céus a tromperie que inspira os panoramas... Pensemos, isto sim, na desconcertante subtração da presença humana e do tempo que passa nas chamadas naturezas mortas. Foi bem mais a partir destas cenas de naturezas vivíssimas - como as gaufrettes servidas com um pouco de vinho de Baugin, como os limões amarelos de Zurbaran ou, trazendo estas questões para mais perto, como os abacaxis e cajus que Eckout nos servira-que muitos artistas, estetas, filósofos e os pintores de panoramas destes 
finais do século XVIII começaram a afastar de modo cada vez mais nítido, as sombras dos deuses. É delas, do peso deste mundo imanente, onde cada coisa é tão coisa que parece estar num espaço outro, mais real que o real, é desta objetualidade vista por um sujeito oculto, que os panoramas se servem para criar seu espaço de puro presente...

Na pintura barroca de um modo geral e no hiper-realismo das naturezas mortas de modo particular, temos uma lição bidimensional do que os panoramas ambicionaram: transformar, justamente, em experiência global única e una - fechada, plena e sem saída, o embate de cada um com aquilo que vê e o cerca. Um embate, como já dissemos, que induz à reflexão sobre a liberdade e a história e que, cada vez de modo mais claro, perturbadoramente questiona a idéia de espaço e de tempo, entendidos como conceitos estáveis.

Com os comentários de Diderot, por volta de meados do século XVIII, talvez possamos entender, isto sim, como esta "presentificação" do mundo visível alcançada pela tromperie da pintura invade o primeiro plano das discussões do período (cf. Starobinski 1991). As observações sobre as azeitonas de Chardin, por exemplo, iá não são só especulações íntimas de um pintor, mas elas são detalhadamente analisadas e são tornadas públicas pela crítica. A verdade da tela, com Diderot, é medida pelo seu livre atravessar nos dois sentidos: pelos objetos representados e pelo espectador. Mas mais que isso, este processo passa a ser apontado, racionalizado, compartilhado. A superfície plana e pintada é um passeio, uma exploração, uma viagem: "O triunfo da magia pictural é que esqueceremos que estamos diante de uma tela: explora-se a verdade sensivel do mundo" (ib.)

Complementar e paralelamente, a busca de sistematização das formas de percepção - claras ou indistintas - e com ela, de reflexão sobre a vertigem mas também sobre a verdade dos sentidos, penetra o próprio campo da filosofia. Neste sentido, a redação da Aesthetica, como teoria e ciência do conhecimento sensivel por Baumgarten, em meados do século XVIII, é um sintoma do interesse, que, até mesmo os filósofos, embora ainda de modo reticente, começam a dedicar a assuntos até então dispersos ou restritos aos debates sobre a arte e a poesia (cf. Croce 1991). A Aesthetica dá mostra ainda deste deslocamento do discurso sobre a imaginação e o sentimento da esfera da teologia.

Entretanto, introduz-se aqui o tema da natureza. Desde o final do século XVI, ele começa a pressionar o espaço pictural, graças ao impacto da poesia idílica e dos relatos sobre os descobrimentos americanos. Mas os pintores italianos, devido a preeminência da encomenda religiosa, fixaram-se preferencialmente na figura humana e na "expressão trágica de seu destino" (cf. Conan: 1991 e Roger: 1991). Com Lorrain e Poussin prevalecem justamente as cenas virgilianas envoltas de um idealismo clássico e é esta tendência, presente na obra de Vernet, por exemplo, que Diderot começa por celebrar até vislumbrar, isto sim, que o horizonte humano é urbano, social, político e histórico. O idílio é impossivel (Starobinski 1987 e 1991). Esta a sua mais importante contribuição para o seu tempo e para a história da cultura. Com ele, - motivo determinante passava a ser a vontade de dar forma e não a vontade de contemplar (cf. Cassirer 1988: 37-38). 
A Holanda, desde o início do século XVII, percorrera outra vertente, aquela das naturezas-mortas, aquela dos croquis de observação direta da natureza. Feitos até mesmo por Carrache, Poussin e Lorrain, estes desenhos não eram trazidos a público e não eram considerados obras de arte (Conan 1991). Foi se fixando nos espetáculos prodigiosos da natureza que os filósofos acreditaram poder escapar do que falava a arte oficial barroca, tanto com o idealismo das cenas campestres quanto com o derramamento dos sentidos de corpos de santos, demasiadamente humanos. Por outro lado, foi considerando a pintura de paisagem como uma filosofia natural que diversos pintores, como Constable por exemplo, (cf. Bordini, 1984) pressionam para uma gradual mudança no estatuto da arte.

De Baumgarten a Kant (Cassirer, 1995), a reflexão em torno da interação entre sujeito, natureza e o arrebatamento do pensamento aponta cada vez mais para a questão da "relação" e do "absoluto", isto é, o que não tem medida, não tem relação, não tem limite: liberdade e história. Mas, numa cultura atenta a dispositivos "parlants" esta experiência do absoluto parecia poder ser experimentada diante de cenários naturais infinitos, ou como o interesse da segunda metade do século XVIII começa a demonstrar cada vez mais, através da pura interioridade oferecida pelas formas circulares. De fato, o terror da "grande nature" e a estética do infinito são indissociáveis do seu par a saturação da experiência dos limites materiais presente nas formas esféricas e numa "architecture des ombres" (Siedlmeyer 1959: 27 ). Vimos como isto, anedoticamente, aparece até mesmo nos relatos sobre a invenção de Barker.

Talvez o desejo de arte total expresso nos panoramas possa ser vislumbrado no barroco, com o nascimento da ópera. Entretanto, projetando os indivíduos em "histórias" e num cenário que podia ser observado como "exterioridades", nem thes atribuia um papel central nem os colocava em uma situação fechada e envolvente fisicamente. Estaria reservado aos panoramas, graças, respectivamente, à arquitetura e à pintura, esta unidade física e visual.

As formas do indeterminado

Assim, instruído desde o barroco pela pintura, o olhar toma prazer na contemplação da grandeza na natureza, mas também nas construções humanas. "Por grandiosidade, - escreve Addison -, não quero designar a massa de um objeto simples, mas a extensão de tudo o que vemos e quase simultâneamente podemos apreender como uma espécie de todo" lapud Starobinski 1978: 166).

O Pantheon em Roma havia sido, em outro momento, intenso exercício da idéia de indivíduo, a construção que postulou o problema dos limites e materializou esta "submissão de todas as partes à unidade absoluta do todo" lapud Patteta 1984: 76-77). Com ele expandira-se, inclusive, o entendimento da arquitetura: de superfícies articuladas visíveis à interioridade que se experimenta com o corpo. Realizou o que até então parecia irrealizável: permitiu que o conceito de espaço fosse caracterizado.

No Pantheon, como mostrou Alois Riegl (ib.), para onde quer que o espectador olhe, sempre encontra superfícies inconclusas que nunca se realizam 
na forma, que sempre remetem para elas próprias. Deste modo, sua proposta circular e envolvente ao fazer o espectador buscar amparo para o othar - um parâmetro - na terceira dimensão e encontrá-la apenas parcialmente ou de modo incompleto, acaba por despertar a consciência dos limites materiais e apelar para a ajuda integradora da consciência subjetiva.

Roma, que "inventara" o retrato, também colocara o homem espacialmente no centro das coisas. É dela que Brunelleschi extraíra a sua cúpula fazendo do arquiteto e da sua prática a expressão mesma do humanismo. Na segunda metade do século XVIII, as formas circulares e esféricas impõem-se cada vez mais. $O$ que se vê nas pranchetas dos arquitetos Ledoux e Boulée são os exemplos mais evidentes. A interioridade, expressionista, densa, explode também nas "Prisões" de Piranesi. É desta centralidade - grave, em abismo - que os românticos mais tarde, particularmente na Alemanha, "exprimem seu sentimento da impossibilidade da consciência livre se submeter a uma forma determinada, fechada sobre si própria" (Starobinski 1991).

No caso dos panoramas, a circularidade da tela, evidentemente, trabalha na mesma direção e a performance técnica, tanto quanto a representação, devem ser instrumentalizadas apenas como estímulo que suscita no espectador uma reação. É num campo especulativo que postula o problema da "expressão do artista", da "impressão" causada pelo objeto artístico no espectador e, particularmente, em ambos os casos, da "experiência da arte" como experiência reflexiva do sujeito - que os panoramas e sua formalização se inserem e contribuem a fazer pensar.

A frase de Schlegel, "a paisagem como tal só existe no olho de seu espectador", formulada nesses anos de invenção do panorama, esclarece a ambição da iniciativa de Barker. Ela é o rebatimento da gravura de Ledoux que faz coincidir com o olho o teatro do mundo. O que parece tornar-se cada vez mais evidente com estas pinturas que parecem projetar os homens em paisagens e em cenas é que "tem-se a consciência de que tudo não passa de uma projeção" e é esta situação "ambígua", "contraditória" Ina palavras de Schlegell, que interessa agora do ponto de vista estético. A pintura moderna em sua concepção seria "como um fragmento recortado do espetáculo ótico do mundo", em que a contemplação seria como que uma fase de abertura ao mundo e um retorno do sujeito sobre si (Recht 1989).

Neste sentido, os panoramas parecem querer ser um convite à realização da frase de Goethe: "O homem não goza e nem experimenta nada sem ser ao mesmo tempo criativo. Esta é a qualidade, a mais íntima, da natureza humana. Sim, podemos afirmar sem exagero, que esta é a própria natureza humana" (apud Cassirer 1995:82).

Expande-se, consequentemente, o campo de atenção do artista, que passa a interferir na forma como as obras de arte são "exibidas", "montadas", "iluminadas". Com estas discussões esboça-se a moderna museologia (Recht 1989) mas é evidente o seu impacto nos processo de autonomização da obra de arte que se observa, particularmente após meados do século XIX, com os impressionisłas e Cézanne. 
Os temas - primeiros deslocamentos

Inicialmente, embora revolucionária, a invenção de Barker obtém um sucesso "modesto", devido, entre outros fatores, ao tema exibido: o primeiro panorama retratava uma frota inglesa ancorada entre o Portsmouth e a litha de Wight. Foi somente a partir do terceiro panorama exibido, mostrando justamente uma vista urbana - de Londres -, que os visitantes não mais hesitaram em afirmar que estavam diante de um dos maiores progressos realizados nos últimos anos na arte de pintar.

Entre 1799 e 1800, os panoramas haviam chegado à França e à Alemanha enquanto em Londres adquiriam um alto nível de sofisticação. Na França ele seria objeto de um relatório apresentado ao Institut pelo arquiteto e pintor Dufourny, naquele ano, onde seu caráter inovador será realçado. Nesse momento, os panoramas são objetos de curiosidade que interessam tanto às novas camadas urbanas como aos especialistas. David levará seus alunos para olhar no boulevard Montmartre em Paris os primeiros panoramas pintados por C.M. Bouton ltambém seu aluno), C. Bourgeois, D. Fontaine, J. Mouchet e Pierre Prévost (aluno de Henri Valenciennes), na rotunda construída por James Thayer (Bordini, 1984).

As dimensões das construções eram enormes - 10 a 15 metros de altura e 30 a 35 metros de diâmetro - e, evidentemente, correspondiam também às dimensões das telas ai exibidas. $O$ impacto destas pinturas era tão forte que numa de suas visitas, David - atraído para o "interior" destas telas - não conseguiria conter seu entusiasmo e incitaria seus discípulos a aprender a estudar a natureza a partir da experiência sensivel destas telas: "É aqui senhores que devemos vir" (D'Helft \& Verliefden, 1978).

Longe de ser uma frase de incitamento à contemplação da natureza como "objeto", plena e perfeitamente representada no panorama que vê, a frase de David, que já pintara o seu Marat, mostra que com Diderot a antiguidade, a natureza, a ingenuidade eram modelos que se afastavam (Starobinski, 1991). É a atualidade, é o presente, tal como a retórica barroca, dispersamente, começara a ensinar, que invade, com os panoramas, o campo da pintura. O comentário de David sublinha o deslocamento que se opera, então, em relação às coisas naturais, elas mesmas vistas como - o que nos parece hoje evidente - históricas.

A natureza não é objeto "em si", é motivo, incitação, estímulo. É aprendizado ético, lúcido, da liberdade e dá história. É como se David, diante do "hiper-realismo" do que olha, extraísse do interior de seu classicismo a intuição da mesma mensagem partilhada com tantos outros artistas depois dele: "o mundo não é um espetáculo que se há de admirar mas uma experiência a ser vivida e a pintura é um modo de vivê-la" (cf. Argan 1975).

Mas, se os panoramas devem introduzir os espectadores ao "sentimento" da natureza, que é o fundamento da consciência histórica e da moral, o que figurar nessas telas, é o que se interrogam uns e outros neste começo de século XIX. Existiria ainda um tema (um objetol capaz de intensificar esta experiência? Seria a natureza ou a cidade? $\bigcirc$ passado ou, justamente, a atualidade? A paz ou a guerra? Pode-se representar a natureza ilimitada ou deve-se restringir a figurar a ilusão momentânea em que a captamos? 
Em 1801, uma leitora do Journal des luxus und der Moden responderia a algumas destas indagações declarando: "... para mim los panoramas deveriam mostrar) somente assuntos que são calmos... Paisagens sublimes. Sobretudo aquelas que figuram uma recordação, uma lembrança: o cemitério de Vevey, Chamonix ou o Mont Blanc, as geleiras e as cascatas, todos os templos da natureza, locais inacessíveis... Estes devem ser o campo de intervenção dos panoramas. Neles estão toda sua arte. Tudo o que seja guerra ou tráfego urbano, tudo que é transitório será desprezado, relegado e aqueles serão os temas capazes de dizer se os panoramas são uma nova expressão de arte ou uma loucura passageira" (D'Helft \& Verliefden 1978).

Com os panoramas a existência de um ideal temático ou formal estabelecido a priori deixa de ser "naturalmente" aceito: tal como fora entendido e cerceado nos primórdios do barroco a forma é resultado da maneira do artista ver e experimentar o mundo. Os panoramas nesse início de século trabalham no sentido de transformar o problema da pintura em problema da visão.

Na Alemanha, o impacto das pinturas de panorama sobre a geração romântica é enorme. Desde 1788 um decorador de teatro berlinense, Johann Adam Breysig (cf. Bordini 1984), reivindica de modo aparentemente independente das pesquisas de Barker a idéia de exibição de telas nos moldes do panorama inventado pelo escocês. Breysig, com a ajuda do paisagista Kaaz, construirá o primeiro panorama naquele país.

Veremos os vestígios das teorias inspiradas pelas observações deste gênero de pintura, tanto nas discussõs sobre a exposição de obras de arte lpor ocasião, por exemplo, da construção de novas pinacotecas por Schinkell, como nas pinturas de Friedrich. Schinkel havia, em 1808, exposto um panorama de Palermo (cf. Plessen ed. 1993) e são, certamente, as idéias extraídas das suas experiências que guiam a revolução que realiza contra o sistema de exibição até então utilizado e que colocava as telas no alto e "misturadas", umas ao lado das outras. A vivência de um panorama ensina a buscar formas de isolar o objeto de modo a enfatizar a interação do olhar com o que é olhado lapud Recht 1989: 122-123).

Friedrich, por sua vez, desde pelo menos 1810, manifestaria seu interesse e sua vontade de pintar de modo panorâmico. Embora não o tenha realizado, insistentemente fixou-se no tema da janela - interseção e identidade exterior/interior tão fortemente presente na história da pintura e tratado de forma extrema na concepção dos panoramas.

Desenha-se a crise em torno da representação que se perceberá de forma cada vez mais aguda na segunda metade do século XIX no campo da pintura, sua função, seus instrumentos.

De fato, isolando o espectador, o panorama quer the dar a estrutura de um sujeito livre de todo pertencimento ao tempo, para que ali, no centro da sala iluminada do alto, diante da obra, ao buscar reproduzir uma experiência estética realizada pelo artista - numa duração real ou simulada - cada qual possa dotar de espessura o conceito de história.

Goethe, Humboldt, Chateaubriand, Balzac, Baudelaire, Van Gogh: a lista é enorme dos artistas, escritores ou homens de ciência que de um modo ou outro, deixaram-se tomar pela emotividade na contemplação de panoramas, 
considerando-os obras de arte totais - de alto sentido instrutivo. Naquelas rotundas, diante de paisagens naturais ou construídas, tudo parecia indicar que - espectador se via colocado, como queriam os românticos, diante da experiência exacerbada do mundo sensível que leva à criação artística. O que, talvez, nada mais fosse do que a consciência da potência criativa que é o homem ele mesmo, diante da experiência da liberdade e da história.

Não é à toa que Napoleão, visitando também um destes panoramas, em 1810, vê a conveniência de se utilizar este aparato para popularizar suas vitórias. Até a pintura acadêmica - como vimos com David - parece ceder espaço, em certa medida, ao "espetacular" mas, sobretudo, ao atual, ao agora, a aquilo que se vivencia. É evidente a ruptura que os panoramas operam tanto com a perspectiva de foco central como com a pintura de cavalete. Acentuam-se as preocupações com o enquadramento e com os limites do suporte, que dada a forma circular não tem mais início ou fim. $\bigcirc$ que se observa aqui é a desconstrução gradual da antiga "aderência" (cf. Recht 1989) entre o quadro e a tela, que identificam os limites da percepção com o objeto "representado". Este agora parece ser sem limites. O olho que tudo vê é ainda um olho que vê de todas as maneiras. $A$ grandiosidade das telas acompanha a apresentação crua das coisas e dos fatos. Acompanha, em suma, a grandiosidade - trágica, sem saida - da história.

Ver com os olhos do espírito, ver com os olhos do presente e da vida social: retomam-se e enfatizam-se as figurações da janela e do observador à janela ou em balcões em muitas telas. A reflexão em torno desse olhar do observador $e$ através dele, da comunicação emotiva e de tudo o que diz respeito à recepção da obra de arte, ganha cada vez mais espaço nas discussões do período: o que interessa é construir o espaço de uma experiência. Um presente, um instante.

Desde cedo o olho que contempla um panorama é cada vez mais convidado a ver o que não está mostrado e a sentir. Sentir intensamente. A forma de fruição dessas pinturas deve se realizar, assim, de modo quase religioso, colocando frente a frente, um puro "fora" e um puro "dentro". Sujeito frente a objeto, ambos isolados, sós, únicos. Idênticos, um.

Mas como conciliar este princípio intimista com um aparato que pouco a pouco atrai, pela própria ênfase no sentido do espetacular que vai adquirindo, um número cada vez maior de espectadores? De fato, se até os anos 1820, os panoramas são apreciados por um público cultivado de amadores de arte, a partir de meados da década, eles encantam uma nova cultura urbana, de massa.

Pedaços de papel

Neste ponto, enfim, podemos voltar a buscar compreender a história dos nossos pequenos pedaços de papel pintados em 1822, tecendo as ligações entre franceses e alemães, entre paisagens e "banais" desenhos realizados no Brasil, esquecidos em bibliotecas e museus.

Felix-Emile e Meunié, como membros da Missão Artística de 1816 , seguramente, antes de virem ao Brasil foram frequentadores dos panoramas de Prévost na Passage des Panoramas. Este, como vimos, foi no começo de sua carreira, pintor das primeiras telas circulares exibidas por Theyer. Ao longo da década de 1810 torna-se o mais célebre realizador de panoramas com 
temáticas urbanas e em 1823, quando morre, havia realizado mais de 15 figurações de cidades: Roma, Paris, Toulon, Antuérpia, Atenas, Jerusalém, Florença, Nápoles, etc. (Benjamin 1989: 547). Nunca até Prévost, como declaram seus contemporâneos, a ilusão havia ido tão longe /cf. Bordini 1984: 22). O panorama do Rio de Janeiro foi pintado também para ser exibido na Passage des Panoramas e trata-se assim, certamente, de uma encomenda.

Nestes anos, as telas já haviam alcançado dimensões enormes. Walter Benjamin em notas de pesquisa deixadas sobre o Panorama de Prévost descreve-o como tendo uma circunferência de cerca de 97 metros (Benjamin 1989: 547).

Deve-se assinalar que as técnicas desenvolvidas por Prévost para as figurações eram aperfeiçoadas a cada montagem. Num prospecto informativo sobre o panorama do Rio, publicado em Paris, o autor do texto salienta o caráter absolutamente inovador da realização e a preocupação "científica" que presidiu a prise de vue, isto é, o desenho original de Taunay, e a confecção da ampliação feita pelo pintor Fréderic Guillaume Ronmy (Nepveu 1830 e Denis, Ferdinand \& F.E. Taunay 1824|s.

Os oito quadros que compõem a vista do Rio foram feitos a partir da técnica da "Camera Obscura", conhecida desde a Antiguidade e utilizada largamente no Renascimento por homens como Leonardo da Vinci e Durer. Aperfeiçoada, sucessivamente, por Athanase Kircher no século XVII, e pelo abade Nollet, no XVIII, ela chegava no início do século XIX num formato portátil, derivado daquele desenhado por Nollet em 1771 (cf. Aujourd'hui, art et architecture 1963 e Bordini 1984). Esta mesma técnica deve ter servido a Burchell, com seu panorama de precisão milimétrica. De fato, observando outros panoramas do périodo percebe-se que este aparato já era de uso bastante corrente. Mas as contribuições da ciência à comunicação emotiva romântica não paravam aí.

Certamente no círculo de Prévost as vistas urbanas haviam prevalecido sobre as figurações de cenas naturais mas talvez não porque fossem consideradas os "objetos" ideais a serem retratados. As técnicas desenvolvidas para as pinturas de panoramas foram extremamente sofisticadas: além dos aparelhos óticos, pressupunham a existência de boas bases cartográficas ou relevés capazes de auxiliar a construção da cena em seus detalhes e acabamentos pelo pintor. Além disso exigiam grande virtuosidade nas correções visuais capazes de acentuar a verossimilhança, garantindo ao mesmo tempo regularidade e contundência. Assim, foi até com muita rapidez que em apenas uma década, as cenas urbanas ganharam 0 alto grau de "realismo" já comentado e se impuseram graças, entre outros fatores, ao movimento instigado pelas conquistas napoleônicas que muito contribuiu para o culto das paisagens longínquas, "exóticas", "pitorescas".

Ao longo da década de 1820 as discussões já não envolvem, assim, "motivo". Como vimos, este deixa de ser problema. Trata-se de sublinhar, através do exercício do olhar, uma vivência, o que leva os debates a evoluirem, gradualmente, para a busca de novas técnicas capazes de oferecer ao espectador a sensação de que se acha como que mergulhado em uma cena real, o que desloca as pesquisas nestes anos para outras questões. Assim, se o tema permanece estável - vistas urbanas - prevalece a busca de precisão na "tomada" da cena retratada para melhor criar o efeito ilusionista e aumentam
5. F.G. Ronmy foi aluno de Vien e de Nicolas Taunay. Além do panorama do Rio pintou o de Constantinopla. 
em igual medida as pesquisas sobre os efeitos de luz e cor, capazes de evocar uma ambiência física, provocar uma sensação corpórea.

Pouco a pouco a desmaterialização do objeto buscada pelos panoramas começa a engendrar novas invenções onde o controle e os efeitos de luz são o centro das investigações. Daguerre, que fora aluno de Prévost, inventa em 1822 o diorama, a partir de suas investigações sobre a iluminação dos panoramas como se fossem vistos em diferentes momentos do dia. Dessa forma, ele radicaliza a interação sujeito-obra, alargando a noção de espaço proposta pela forma circular e pela experiência da contemplação dos panoramas, agregando e sublinhando nos seus dioramas a dimensão temporal.

Mas pode-se dizer que, com estes jogos de luz, os panoramas abriam-se para a representação também da noção de movimento e, com ela, para a de duração. Até então, ela estava oculta, era um convite à imaginacão. De certo modo, a "presentificação" vivida nos panoramas reconhecia e até mesmo apelava para o passado (a memória) e o futuro (a expectatival, mas guardava-os potencialmente. O passar das horas: com os dioramas implica um esgarçamento dessa ambiguidade dos primeiros panoramas em relação à suspensão temporal. A mutabilidade, o novo, a viagem já haviam criado uma cultura, que fazia pressão.

Com os panoramas-salon (que permitiam a mobilidade e a substituição rápida das vistas de cidades) e mais tarde com os moving panoramas (que permitiam a simulação de viagens em trens ou descida de rios, percorrendo diversos trechos do percursol a questão passaria a ser a articulação do movimento ao deslocamento físico, geográfico: ao traveling. A noção de história deixava de ser consciência e tensão concentradas - ou tarefa infinita (Cassirer 1988: 50) e passava a ser narrativa.

Vistas urbanas e subjetividades

Em 1816, o pai de Felix-Emile Taunay, Nicolas-Antoine, pintor de telas de dimensões diminutas, conhecido como o Poussin du chevalet, pinta duas telas da área central do Rio de Janeiro, intituladas Morro de Santo Antonio (Figura 3) e Largo da Carioca. Embora de dimensões modestas e sem formar, aparentemente, uma sequência, estas telas são marcadas pelo mesmo tom romântico que impulsionou o surgimento das pinturas de panoramas. Ambas solicitam um olhar que percorrendo a cena mergulha numa atmosfera, num minuto preciso captado pelo pintor. Momento ao mesmo tempo de ação e repouso, momento de vida e contemplação do tempo: assim pintarão o Rio de Janeiro os Taunay, pai e filho. Enquadrando certas vistas sob uma luz difusa e nostálgica, pintará o pai suas pequenas telas. Totalmente luminoso e cheio de promessas registrará ao contrário, seu filho, a visão panorâmica da cidade, anos mais tarde.

De fato, se comparamos o Panorama do Rio de Janeiro de F.E. Taunay com estas telas de Nicolas Taunay veremos várias idéias recorrentes na maneira como estes pintores experimentam e contam a realidade mas também diferenças. A reflexão sobre a história e o presente, a atualidade, está por exemplo em ambos. A pintura de Taunay, outrora pastoral, está aqui tensionada e a visão da cidade não é atravessada por nenhuma luz intemporal. Ao contrário. Da banalidade das cenas de hoje colocadas em primeiro plano frades que 
conversam, ou olham o horizonte com lunetas, grupos de bois que atravessam a malha urbana - o pintor empurra o espectador de plano em plano, para trás, buscando a história através da cidade colonial (nova aos seus olhos) e construindo gradativamente uma visão do "tempo passado".

Oúltimo plano é aquele onde, sem consolo, o espectador contempla a baía de Guanabara. Nesta "retrospectiva" é a natureza que vem ocupar o lugar do monumento, da ruína. Aqui, não se encontra mais o fragmento de antiguidades célebres - como pintava Hubert Robert, amigo de Nicolas - mas, de modo mais radical este acumular-se de ações humanas está sublinhado na visão do Pão de Açucar e na baia, num céu permeado de nuvens cinzas. Olhando estes trabalhos de Taunay sem estardalhaços, vemos que a ambição dos primeiros românticos em tornar a pintura, arte da presença, capaz de exprimir a ausência, parece realizar-se. É como se ouvíssemos Taunay, nos seus sessenta anos, atravessando revoluções, guerras e mares repetir no seu exílio americano, ainda, com Diderof: "(...) Uma torrente arrasta as nações umas sobre as outras para o fundo de um abismo comum e eu, eu só..."

Seis anos mais tarde, o Panorama do Rio de Janeiro, embora contemplando a mesma cidade e buscando esta mesma comunicabilidade já perdeu o tom intimista e reflexivo de Nicolas Taunay e reduzirá a cidade e a natureza de estímulo a espetáculo. O procedimento seguido por Taunay-pai, de ordenação da cena por planos, também se repete no panorama pintado pelo filho. A construção formal parece ser, entretanto, "prospectiva". E como se saíssemos do fundo luminoso da baía e fossemos conduzidos gradualmente até o centro urbano - denso, povoado. Mais luminoso ainda.

Aqui e ali, pedaços de verde, mas são resíduos. A viagem chega até o presente - roupas apenas acabadas de lavar, frutos que pendem das árvores e no alto do morro do Castelo a figura de Pedro l, já Imperador, que se faz acompanhar, a cavalo, por uma comitiva. A cena é clara, a arquitetura mostra contornos bem desenhados, e as casas são apresentadas com seus telhados nivelados, ordenados, cercando os diversos "monumentos". No fundo, a baía de Guanabara em sua versão radiosa. Tudo parece em equilibrio e a única promessa de ação vem dos homens que estão na comitiva. A cena registra um acontecimento, dota o que seria corriqueiro - um passeio a cavalo do Imperador (uma visita específica?) - de uma espessura e convida à reflexão. Mas é em direção ao futuro "a criar" - à jovem nação a pouco independente que o pintor busca nos conduzir.

Porque teria F.E.Taunay introduzido neste panorama a ser exibido na Europa a figura do Imperador? Ainda mais apenas declarada a Independência? Qual significado atribuir a este gesto? "J'ai pris ces vues..." $1 \mathrm{Ou}$ teria sido Meunié, perpełuando acontecimentos que vira... Já nostálgico diante de seu retorno, iminente, à França ...) "Il est deux ou trois heures du soir... La marée commence à descendre...

Na observação da ambiguidade do problema da autoria, constatam-se não só os deslocamentos de um gênero de pintura - o de paisagens - observados entre Nicolas e Felix Taunay, mas, também, uma mutação nos panoramas, em relação pelos menos às discussões da década de 1800/1810.

Identificamos pelo menos cinco desenhos panorâmicos do Rio de Janeiro nesta década, que talvez possam nos ajudar a comparar e tecer algumas conclusões. 
Se designassemos o Panorama do Rio de Janeiro como registro pessoal (Meunié) ainda poderiamos colocar ênfase no desejo de fixação do tempo, das impressões, como outros dois panoramas desenhados naquela década? De fato, dentro desta ótica, ele viria se alinhar com o panorama de Maria Graham (1825) e o de Emeric Essex Vidal (Fundação Castro Maya - 1827) - tomados do centro da Baia da Guanabara - águas e montanhas que circundam o olhar...

Mas dificilmente as aquarelas do nosso Panorama, a despeito dos comentários sobre as horas, a luz, a maré poderiam ser colocadas no campo dos registros pessoais. Elas aspiram a cientificidade: o ponto de vista é distanciado, privilegiando a cidade. $O$ embate com esta e com o meio natural está neutralizado ou quase não existe: está distante, mediado pela palavra. $O$ sujeito afirmado no " $j e$ ", observa a cidade e a Baia do alto. Ela se mostra rigorosamente clara.

O panorama de Burchell, num certo sentido, poderia ser cotejado com o Panorama francês. O ponto de vista é também "aéreo" - a partir do Morro do Castelo - mas de um sítio bem mais baixo em relação à cidade. Burchell registra, certamente com a ajuda de uma câmara, a cidade, detalhadamente. Mas sua intimidade com a vida urbana é bem maior do que aquela demonstrada no Panorama do Rio de Janeiro e nos desenhos de Graham e Vidal. A natureza, aqui, também ocupa o primeiro plano. Na verdade, bananeiras e casas, estão lado a lado mas os contornos de umas e de outras são tingidos de luz, matizes. Tudo se mostra quase em movimento. Não há palavras que descrevam a atmosfera. Elas seriam supérfluas..

O quinto panorama foi desenhado por Debret (Fundação Castro Maya - s.d. ca. 1825). Aqui o pintor se colocou no cume da mais alta montanha da cidade. Observam-se os manguesais, os recortes sinuosos da Baia, as áreas urbanizadas, mas tudo está infinitamente distante, sob o controle do lápis de cor que marca aqui e ali alguns tons mais vivos. Sujeitos cada vez mais distantes - com um olhar cada vez mais absoluto, mas também cada vez mais desengajado... Cenas retratadas de longe: a história cada vez mais entendida como "narrativa" e visão "descritiva e apartada" dos fatos...

Voltemos ao Panorama do Rio de Janeiro. Na notícia que Nepveu escreveu sobre o panorama-salon também existiam indícios destas mudanças. Nepveu explicava, por exemplo, que começara a colocar no mercado o seu panorama portátil pela vista do Rio mas era possuidor de uma coleção de desenhos com as principais cidades do mundo. Estas vistas haviam sido tomadas sur place, com a chambre noire, porque se evitavam assim esses "dessins spirituels mais souvents inexacts, des plus habiles peintres" (Nepveu 1830).

As cenas "tomadas" a partir de um aparelho ótico não permitiam fixar o que se movimentava. A figura do Imperador - quase uma reportagem em visita ao Castelo, foi anexada, provavelmente, a posteriori, à composição. Como mais tarde, nas sucessivas gravuras, a partir da década de 1830, todas de pequeno formato, que se utilizaram destes desenhos como base. Enriquecidas com figuras de papagaios, perfis de varanda em lambrequins, estas reproduções provavelmente com centenas de outros desenhos de cidades ou de montanhas eram vendidas como souvenirs ou para serem vistas em panoramas-salons (mais cômodos) ... Viagens confortáveis, realizadas, agora sem riscos. Sem conflitos... 
No Panorama de Felix-Emile, isto ainda é apenas sintoma. Como em Nicolas Taunay, natureza e cidade estão sujeitas à vontade e à ação dos indivíduos. "Da subjetividade do sentir à subjetividade do querer" (Starobinski 1987) esta parece ser, entretanto, a diferença destes desenhos, de pai e filho, de mestre e discípulo sobre a cidade.

Como dissemos, tudo leva a crer, dadas as circunstâncias em que foi realizado, que este panorama é uma obra encomendada por Prévost. Mas como entender este grupo? Como entender o sucesso que conheceu a exibição deste panorama do Rio em Paris, capaz de engendrar a invenção de um novo aparelho ótico - o panorama portátil (panorama-salon), destinado a enfeitar os salões pequeno burgueses e que causou uma febre de reproduções destas vistas do Rio, realizadas a partir do desenho original, dentre as quais aquelas encontrada nos acervos cariocas? Como entender - no âmbito dessa teoria da paisagem que surge e circula entre ingleses, alemães e franceses - este sucesso da baía de Guanabara nunca se entregando como mero objeto de contemplação, capaz talvez até mesmo de levar os copistas do desenho de Burchell à "mentira" sobre a data de sua empreitada?

Nova objetividade

Prévost morrera em 1823, mas deixara discípulos que levavam suas pesquisas com as imagens e as formas de exibição por novos caminhos. Num tolheto explicativo distribuido aos visitantes, Daguerre explica os objetivos de sua nova invenção: "Acrescentar os prodígios da animação às ilusões conquistadas pelo gênero panorama (...) problema há muito tempo formulado e até então sem solução. Encontrar os meios de tornar (sensivel) os aspectos da natureza $(\ldots)$ com as impressões das diversas mudanças que ocorrem com o vento, a luz, os vapores, em um tempo dado ..." (cf. Aujourd'hui 1963).

Quando nosso panorama do Rio é exibido em 1824, em Paris, estamos realmente a um passo de duas grandes revoluções: a invenção da fotografia e da arte de projetar imagens em movimento e a difusão no campo da pintura das "modernas" técnicas de uso da luz e da cor de forma não a descrever mas a ativar a memória de uma experiência que está em cada um.

Quinze anos mais tarde, em 1839, ano em que a invenção da fotografia era tornada pública, o diorama de Daguerre, sintomaticamente, pegava fogo. Alexander von Humboldt, figura central do romantismo alemão, membro do Institut de France, frequentado por alguns dos franceses que vieram para o Rio, admirador de panoramas e dioramas, tomava, agora, a tarefa de defender o mais recente invento do antigo aluno de Prévost: o daguerreótipo.

No plano científico, neste final de anos 1830, vemos assim, o advento da fotografia. No plano das mentalidades, vemos a lenta sedimentação da cidade enquanto espaço a ser conquistado, corrigido, melhorado pela vontade dos homens e a idéia de panorama invadir até mesmo o campo literário. A revolução realizada pelo invento de Barker já havia dado novos frutos e os próprios panoramas perderiam agora gradualmente seu papel de condutores de pesquisas plásticas, estéticas ou científicas embora mantivessem, como é frequente acontecer, seu fascínio sobre as massas. 
Retomando as dúvidas da leitora do Journal des luxus und der Moden, talvez pudéssemos dizer que os panoramas haviam sido uma nova expressão de arte e estavam prestes a se tornar uma loucura, no fim das contas, passageira.

Demolidas as rotundas, rasgadas as telas, incendiados inúmeros dioramas, desses tempos de construção da sensibilidade moderna restaria a força das palavras de Baudelaire sobre a cidade e sobre os locais e experiências onde aprendera a conhecer o abismo anônimo dos novos tempos (Baudelaire 1968). Sobre estas rotundas inundadas de linhas e luz - cidades sem janelas como mais tarde as chamaria Benjamin - o poeta francês escreveria: "Desejo ser levado a estes dioramas onde a magia brutal e enorme sabe impor-me uma ilusão útil. Prefiro contemplar alguns destes décors de teatro onde encontro artisticamente expressos e tragicamente concentrados meus sonhos - os mais caros. Estas coisas, justamente por serem falsas, estão infinitamente mais próximas do verdadeiro, enquanto a maioria dos nossos paisagistas são mentirosos justamente porque esqueceram de mentir".

\section{BIBLIOGRAFIA}

ARGAN, Giulio Carlo. El arte moderno. Valencia: Fernando Torres, 1975.

ARGAN, Giulio Carlo. L'Europe des capitales: 1600-1700. Géneve: Skira, 1964.

AUJOURD'HUI, ART ET ARCHITECTURE, n.42-43, p.64-65, oct. 1963.

BEAUDELAIRE, Charles. Salon 1859. In: Oeuvres complètes. Paris: Seuil, 1968.

BELUZZO, Ana Maria Moraes. O Brasil dos viajantes. São Paulo: Metalivros, 1994. v.3

BENJAMIN, Walter. Paris capitale du XIXème siècle. Paris: Cerf, 1989.

BERQUE, Augustin, ed. Cinq propositions pour une théorie du paysage. Paris: Champ Vallon, 1994.

BORDINI, Silvia. Storia del Panorama: la visione totale nella pittura del XIX secolo. Roma: Officina, 1984.

BRION, Marcel ed. Caspar David Friedrich, Carl Gustav Carus: de la peinture de paysage. Paris: Klincksieck, 1988.

COHEN, Jean-Louis. Scènes de la vie future. Paris: Flammarion/Centre Canadien d'Architecture, 1995.

CONAN, Michel. Généalogie du paysage. Le Débat, n.65, p.29-42, 1991.

COMMENT, Bernard. Le XIXe siècle des panoramas. Paris: Adam Biro, 1993.

CHOAY, Françoise. La régle et le modèle. Paris: Seuil, 1979.

CROCE, Benedetto. Essais d'esthétique. Paris: Gallimard, 1991.

CASSIRER, Ernst. Ecrits sur l'art. Paris: Cerf, 1995.

CASSIRER, Ernst. L'ídée de l'bistoire. Paris: Cerf, 1988. 
DAMISCH, Hubert; COHEN, Jean-Louis. Américanisme et modernité: l'idéal Américain dans l'architecture et l'urbanisme. Paris: Flammarion/EHESS, 1993.

DAVID ROY, Marguerite. Le Rio de Janeiro de Louis-Synphorien Meunié. Archives d'arcbitecture moderne, n.40, 1990.

D'HELFT, Brigitte; VERLIEFDEN, Michel. Les rotondes de l'illusion. Monuments bistoriques, n. $4,1978$.

EPUCHE, Albert Garcia, org. Ciudades: del globo al satélite. Barcelona: Centre de Cultura Conteporània, 1994.

FERREZ, Gilberto. O mais belo panorama do Rio de Janeiro. Rio de Janeiro: IHGB, 1966.

GUSDORF, Georges. Le savoir romantique de la nature. Paris: Payot, 1985.

GUSDORF, Georges. Le romantisme. Paris: Payot, 1993. v.1.

JAY, Martin. Downcast eyes: the denigration of vision in twentieth century French thought. Berkeley: University of California Press, 1993.

LEVIN, David Michael. Modernity and begemony of vision. Berkeley: University of California Press, 1993.

NEPVEU, ed. Des panoramas-salon: explication du panorama de Rio de Janeiro. Paris: Passage des panoramas, 1830.

PATTETA, Luciano. Historia de la Arquitectura: antologia critica. Barcelona: Hermann Blume, 1984.

PEIXOTO, Elza Ramos. Vitor Meireles e os Panoramas. In: Vitor Meireles de Lima: 1832-1903. Rio de Janeiro: Pinakotheke, 1982.

PEREIRA, Margareth da Silva. O solar de Grandjean de Montigny na Gávea nos desenhos de Louis-Synphorien Meunié. In: Morada carioca. Rio de Janeiro: PUC, 1992. (catálogo).

PEREIRA, Margareth da Silva. Rio de Janeiro, l'épbemère et la pérennité. Paris, 1988. Tese Ecole des Hautes Etudes en Sciences Sociales.

PLESSEN, Marie-Louise von, ed. Sebsucbt: Das Panorama als Massenunterhaltung des 19. Jahrhunderts. Bonn: Stroemfeld/Roter Stern, 1993.

RECHT, Roland. La lettre de Humboldt. Paris: Christian Bourgois, 1989.

ROGER, Alain. Le paysage occidental. Le Débat, n.65, p.14-28, 1991.

SEDLMEYER, Hans. El arte descentrado. Barcelona: Labor, 1959.

SENNET, Richard. The conscience of the eye: the design and social life of cities. New York: Alfred Knopf, 1990.

STAROBINSKI, Jean. L'invention de la liberté. Genève: Skira, 1987.

STAROBINSKI, Jean. Diderot dans l'espace des peintres suivi de "Le sacrifice en rêve". Paris: Réunion des Musées Nationaux, 1991.

SZONDI, Peter. Poésie et poétique de l'idéalisme allemand Paris: Gallimard,1975. 


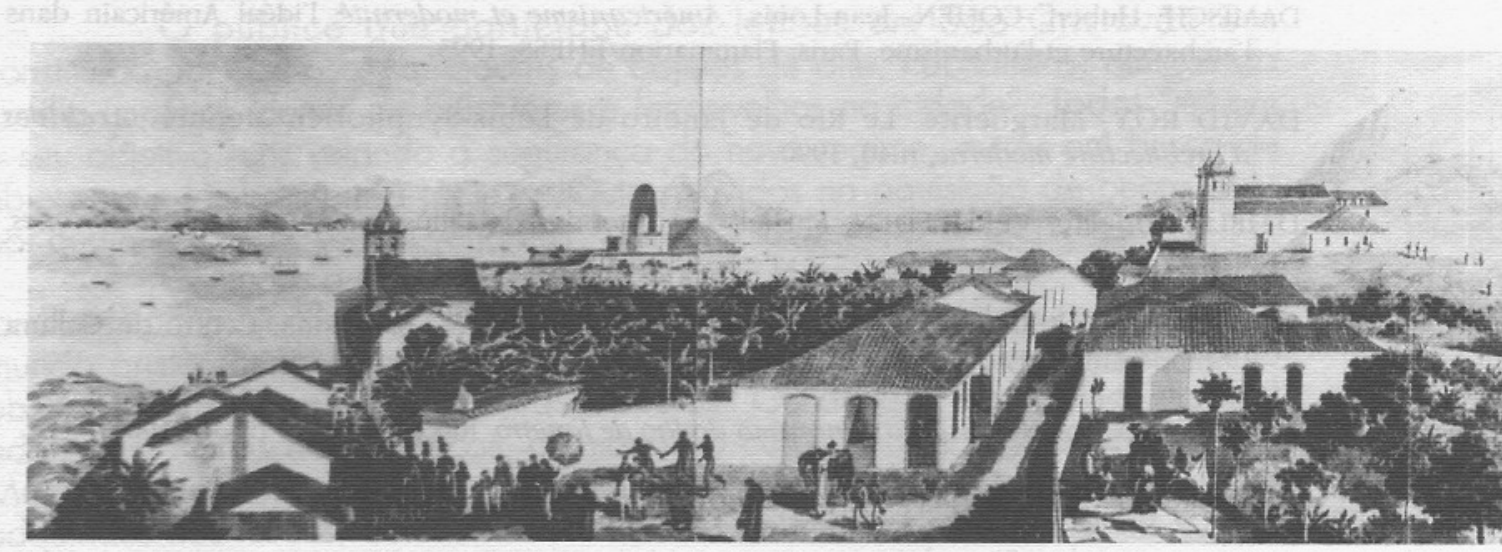

Fig. 1 - Panorama do Rio de Janeiro (parcial) c. 1823. Aquarela, $51 \times 312 \mathrm{~cm}$. Coleção família Meunié David-Roy.

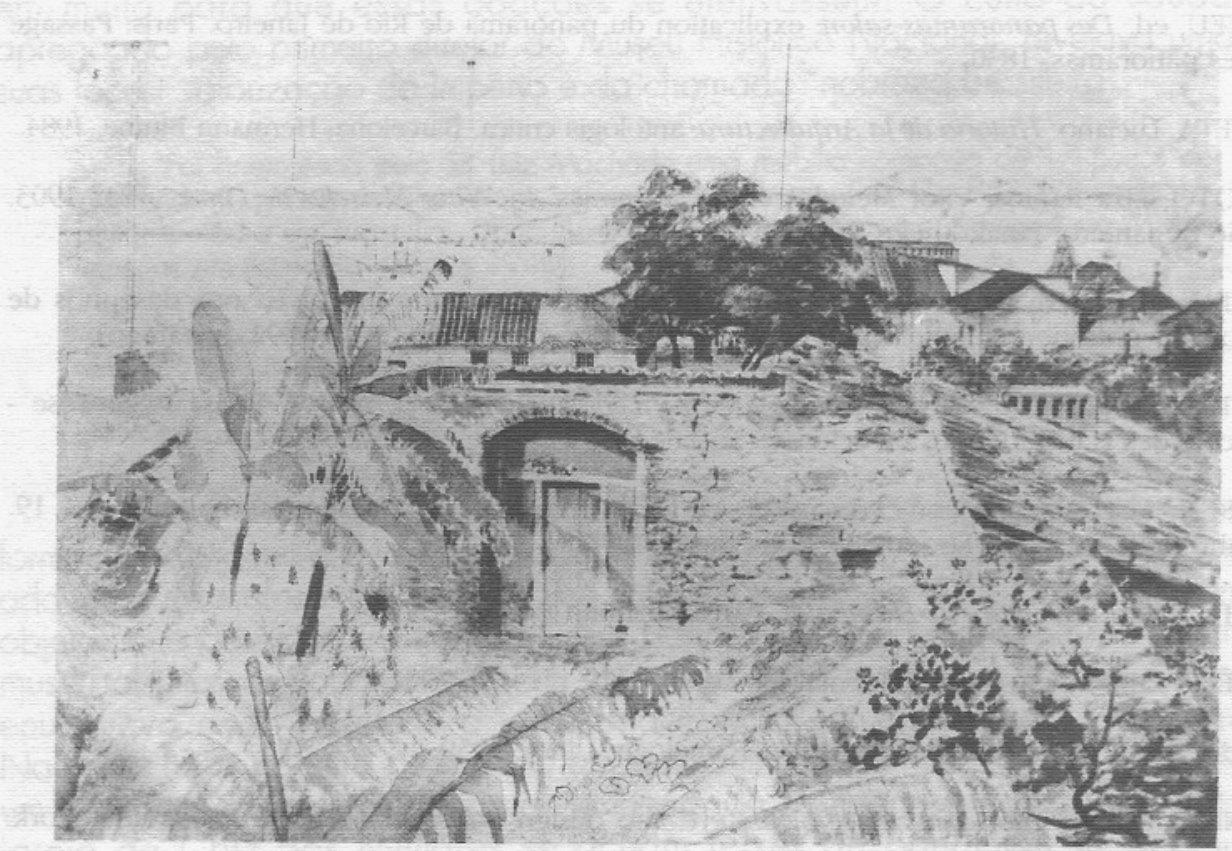

Fig. 2- William John Burchell (1781-1863).O mais belo panorama do Rio de Janeiro (detalhe), 1825. Bico de pena e aquarela (Reproduzido de Ferrez 1966, edição do Instituto Histórico e Geográfico Brasileiro). 
Romantismo e objetividade: notas sobre um panorama do Rio de Janeiro

Enfoca orande Panorama do Rio de Janeiro, exibido em Paris em 1824, Margareth da Silva Pereira do qual se conhece a série de aquarelas que serviram de base tanto àquela ampliação quanto às sucessivas gravuras da cena que foram produzidas na década de 1830. Busca-se mostrar como os panoramas em sua formalização inicial dialogam com as teses do romantismo e da Naturphilosophie, mobilizando heranças da pintura seiscentista. No desenvolvimento desta forma de exibição as aquarelas do Rio apresentam sintomas do gradual afastamento das ambições iniciais através do tratamento dispensado ao sítio natural e à cidade. Por fim, a invenção do daguerreótipo, e as vistas urbanas em vôo de pássaro, entre outros, balizariam a mudança de sensibilidade na produção e na fruição dessas telas circulares. A partir de 1840/50 os panoramas engendrados pelo desejo de fusão entre arte e ciência e pela reflexão sobre a natureza e a liberdade, tornar-se-iam, sobretudo, um divertimento de massas.

UNTTERMOS: Panorama. Panorama do Rio de Janeiro (Paris, 1824). Convenções visuais oitocentistas. Romantismo.

Anais do Museu Paulista: N.Ser. v.2, 1994

Romanticism and objectivity: noles on a Panorama of Rio de Janeiro

Margareth da Silva Pereira

The article deals with the great Panorama of Rio de Janeiro exhibited in Paris, 1824, and its sources - a series of watercolours which have also generated succeeding engravings produced during the 1830s. Panoramas, in their early formal conventions are shown to interplay with Romanticism's and Naturphilosophie's theses and to put in motion the legacy of 17th-century painting. As this genre of visual device develops, Rio's watercoulours display symptoms of a gradual dismissal of its initial ambitions, through the treatment of the natural site and the city. At last the invention of the daguerreotype and vol d'oiseau urban images, among other traits, signaled the changes in sensibility related to the production and consumption of those circular canvasses. From $1840 / 50$ on panoramas conceived by the will to fuse att and science and by a reflection on nature and liberly turn essentially into a mass entertainment.

UNITERMS: Panorama. Panorama of Rio de Janeiro (Paris, 1824). 19th-century visual conventions. Romanticism. Anais do Museu Paulista: N.Ser, v.2, 1994

História de uma coleção: Miguel Calmon e o Museu Histórico Nacional

Regina Abreu

Retraçando a trajetória da Coleção Miguel Calmon, doada ao Museu Histórico Nacional, no Rio de Janeiro, em 1936, estabelece seu significado no contexto histórico e ideológico daquela instituição, que a expôs desde seu ingresso, até seu desmonte, no final da década de 1960. São duas as reflexões centrais: a primeira sobre a noção de história subjacente ao modelo de museu que vigorou no Museu Histórico Nacional desde sua fundação, em 1922, até aos anos 1960; a segunda sobre a construção do personagem Miguel Calmon, apresentado e ritualmente visitado na sala que recebeu seu nome.

UNITERMOS: Museu histórico. Museu Histórico Nacional (Rio de Janeiro). Coleção Miguel Calmon. Gustavo Barroso. Anais do Museu Paulista: N.Ser. v.2, 1994.

History of a collection: Miguel Calmon and the National Historical Museum (Rio de Janeiro)

Regina Abreu

Outlining the career of the Miguel Calmon collection, endowed to the National Historical Museum (Rio de Janeiro) in 1936, the A. unveils its meaning in the historical and ideological context of the museum, which exhibited the grant until the end of the 1960s, when the show was discontinued. Two main arguments are developed: first, the concepts of history underlying the museum paradigm that inspired the Museu Histórico Nacional, since its origins in 1922 until the sixties; secondly, the construction of Miguel Calmon's public persona, exhibited and ritually visited in the room named afer him. 